\section{Peptide Characterization of Mature Fluorotic and Control Human Enamel}

Isabel Maria Porto Lelis ${ }^{1}$, Gabriela F. Molina², Cláudia Souza ${ }^{3}$, Walter B. Perez $^{4}$, Helen J. Laure ${ }^{5,6}$, José C. Rosa ${ }^{5,6}$, Raquel F. Gerlach²

Exposure to high fluoride levels during amelogenesis causes enamel fluorosis. This study aimed to determine and compare the amino acid sequences in the enamel of fluorotic and control teeth. This investigation included enamel samples obtained from erupted and non-erupted third molars with either TF grade 4-6 $(n=7)$ fluorosis or no sign of fluorosis (controls, $n=7$ ). The samples were kept frozen at $-20{ }^{\circ} \mathrm{C}$ until protein extraction. Samples were etched and processed with a cocktail of proteinase inhibitors and immediately analyzed. Matrix Assisted Laser Desorption/Ionization-Time-Of-Flight/Time-of-Flight Mass Spectrometry (MALDI-TOF/TOF) followed by MASCOT search aided the peptides analysis. The more abundant peptides bore the N-terminal amelogenin sequences WYOSIRPPYP (which is specific for the X-encoded amelogenin) and MPLPPHPGHPGYINF (which does not show sexual dimorphism) were not different in control or fluorotic enamel. There was no missing proteolytic cleavage in the fluorotic samples, which suggested that the increased amount of protein described in fluorotic enamel did not stem from the decreased ability of proteinases to cleave the proteins in humans. This study showed how to successfully obtain peptide from superficial enamel. A relatively low number of teeth was sufficient to provide good data on the actual peptides found in mature enamel.

Key Words: protein, proteinases. enamel, mass spectrometry, fluorosis.

\author{
'Department of Morphology, Dental \\ School of Piracicaba, UNICAMP \\ - Universidade Estadual de \\ Campinas, Piracicaba, SP, Brazil \\ ${ }^{2}$ Departament of Morphology, Physiology \\ and Basic Patology, Dental School of \\ Ribeirão Preto, USP - Universidade de \\ São Paulo, Ribeirão Preto, SP, Brazil \\ 3Private Practice, Venâncio \\ Aires, RS, Brazil \\ ${ }^{4}$ Department of Stomatology, \\ Health Sciences Center, UFSM \\ - Universidade Federal de Santa \\ Maria, Santa Maria, RS, Brazil \\ ${ }^{5}$ Departament of Cellular and \\ Molecular Biology and Bio-Agents \\ Pathogens, Medical School of Ribeirão \\ Preto, USP - Universidade de São \\ Paulo, Ribeirão Preto, SP, Brazil \\ ${ }^{6}$ CEPID-CTC Center for Cell-based \\ Therapy, Regional Blood Center of \\ Ribeirão Preto, USP - Universidade de \\ São Paulo, Ribeirão Preto, SP, Brazil
}

Correspondence: Raquel Fernanda Gerlach, Avenida do Café, FORP/ USP, s/n, 14040-904 Ribeirão Preto, SP, Brasil. Tel: +55-16-3315-4065. e-mail: rfgerlach@forp.usp.br.

\section{Introduction}

Excess fluoride in humans and rats causes the hypomineralization phenomenon known as enamel fluorosis $(1,2)$. However, the biological mechanisms underlying this phenomenon remain unknown (3).

Starting in 1975, a series of papers have shown that enamel of animals exposed to fluoride present increased amounts of protein or certain amino acids during the maturation stage (4-8). Later, in 1989, retention of immature proteins and decreased proteolysis in fluorotic rat enamel was described $(9,10)$. Researchers who address the question of how fluoride negatively affects amelogenesis often cite the latter studies. However, the above-mentioned papers dealt with "immature" enamel matrix i.e., enamel matrix in either the secretory or the early stage of maturation.

During the maturation stage, proteins undergo the same degradation pathway in vitro, regardless of the degree of fluoride exposure (11). On the other hand, fluorotic enamel samples do present more intense $\mathrm{C}-\mathrm{H}$ signal in the late stage of maturation, especially on surface enamel. This observation is compatible with the increased protein content found in rat incisors, originated in the presence of high fluoride concentrations as compared with rat incisors formed under control conditions (12). Nonetheless, protein (or peptides) retention in later stages of enamel maturation does not necessarily imply a causal relationship with enamel defects. In fact, the proteins/peptides content decreases over time in enamel that does not contain enamel organ, with a particularly interesting feature: the longer enamel remains inside the bone (intraosseous), the lower the amount of protein in mature enamel (13).

There is growing interest in the treatment and prevention of hypomineralization and fluorosis defects, which recently led to the investigation of the protein composition of hypomineralized enamel. It was shown that hypomineralized enamel from human permanent first molars had from 3- to 15-fold higher protein content than normal, but a near-normal level of residual amelogenins, and this led to typification of this defect as a hypocalcification defect (14). In the light of such findings, it is important to know the composition of the proteins found in fluorotic enamel.

Two studies have investigated which proteins exist in mature fluorotic human enamel. Eastoe and Fejerskov (15) have demonstrated increased ratio of proline-rich protein in fluorotic human enamel as compared with control enamel. Wright et al. (16) have shown similar amino acid profiles in normal and fluorotic enamel, but they described that the protein content increased from $0.1 \%$ to $0.27 \%$, but the standard deviation was high. These two studies used erupted teeth to analyze enamel protein. Therefore, bearing in mind that more porous enamel can incorporate proteins from saliva over time, salivary proteins might also have existed in the samples.

Nowadays, mass spectrometry (MS) techniques constitute superior tools to unravel changes in specific 
proteins, particularly in the case of proteins ranging from 1 to $15 \mathrm{kDa}$, which is the mass range of enamel peptides occurring in mature enamel. Comparison of the techniques used to recover peptides from mature enamel has shown that superficial acid etching is more efficient to obtain amino acid sequences of mature enamel proteins than the cumbersome techniques described in the 1980s $(17,18)$. Amazingly, it is possible to reliably recover enamel-specific peptides from both contemporary teeth and mummy teeth that are over 1,000 years old (19). Unlike the SDSPAGE technique used in the earlier studies cited above, MS identifies specific proteins and amino acid sequences. Additionally, MS is particularly suited to low-abundance peptides, which would have been impossible to detect even by silver staining in gels. MS has found extensive applications: it helps to characterize changes in developing enamel proteins (20-23) and peptides from Molar-Incisor Hypomineralization lesions, where the presence of contaminating salivary proteins is related to lack of integrity of the surface enamel (14).

Given that excellent MS tools are available in the era of proteomics, it is timely to investigate whether there are noncleaved (longer) peptides in fluorotic enamel. The importance that earlier studies have acquired makes MS particularly relevant-some of the first investigations analyzed the presence of enamel proteins and proteinases by SDS-PAGE, which does not resolve proteins $<10 \mathrm{kDa}$, except for the currently available Tricine gels, which have not yet been used to characterize enamel peptides. Finding non-cleaved peptides in fluorotic enamel would prove that, contrary to control enamel, proteolysis does not occur during fluorosis.

So far, no study has compared the peptide sequence in polypeptides present in fluorotic enamel as compared with control ("normal") enamel. Hence, this study aimed to analyze the length and sequences of the most common polypeptides occurring in erupted and non-erupted fluorotic human teeth as compared with controls.

\section{Material and Methods}

All the solutions and salts used in this study were purchased from Sigma-Aldrich (St Louis, MO, USA) or Merck (Darmstadt, Germany) and were high-purity grade. Tubes were manipulated inside a class 100 flow hood cleaned prior to use; gloves with no powder as well as disposable lab coats were employed.

\section{Enamel Samples}

The Ethics Committee for Human Research of the School of Dentistry of Ribeirão Preto (FORP/USP) approved this study (protocol number 2003.1.1329.58.2). The patients were informed about the purposes of the research both verbally and in writing; they signed an informed consent document and a tooth donation term. Patients were invited to donate their third molars for this study only after their tooth extraction has been scheduled for treatment reasons. Fluorotic third molars were extracted in Venancio Aires, a city with 60,000 inhabitants in the State of Rio Grande do Sul, Brazil, after recommendation by three dentists. Cases of fluorosis only occurred in a neighborhood located approximately two miles away from the city center. Indeed, between 2000 and 2003, newspapers reported cases of severe fluorosis in this region, particularly because it prompted public outrage in that community-the condition affected around 3,000 people including adolescents and young adults. The event was attributed to the fact that the water source used by that specific community had approximately $8 \mathrm{ppm}$ fluoride (24). As control teeth, third molars extracted in the Dental Surgery Clinic of the School of Dentistry of Ribeirão Preto) were used. Participants belonging to the control group were also invited to take part in in the study and the purpose of the investigation was explained to them. In the city of Ribeirão Preto, water fluoridation has not been constant in the past decades; no cases of fluorosis have been described in the area. Radiographs of the fluorotic teeth sometimes showed different levels of root formation. Control third molars were matched for donor gender and root formation level $(1 / 3,2 / 3$ or $3 / 3)$ by examination of the radiographs prior to inviting the patients to donate their teeth.

Three control and three fluorotic erupted molars were used in this study. In both groups, one tooth was obtained from a man, and two were extracted from women. Four controls and four fluorotic non-erupted third molars were employed. In both groups, two teeth were obtained from men, and two were extracted from women. Teeth were stored at $-20^{\circ} \mathrm{C}$ until processing.

The Thylstrup-Fejerskov Fluorosis Index was used to assess the degree of fluorosis. Three different examiners determined TF; the concordant result of at least two examiners was recorded. All the seven fluorotic teeth employed in this study showed TF indexes between 4 and 7 .

Protein Extraction and Analysis by Mass Spectrometry Using a Matrix Assisted Laser Desorption/Ionization -Time-Of-Flight/Time-of-Flight Mass Spectrometer (MALDI-TOF/TOF)

The whole tooth crown was submerged in $1 \mathrm{~mL}$ of $10 \%$ hydrochloride acid $(\mathrm{HCl})$ containing proteinase inhibitors for $10 \mathrm{~min}$. Throughout this study, phenanthroline, phenylmethylsulfonyl fluoride, and N-ethylmaleimide, all at a final concentration of $1 \mathrm{mmol}^{-\mathrm{L}^{-1}}$, were used as proteinase inhibitors. The solution was transferred to a microcentrifuge filter with cutoff of $30 \mathrm{kDa}$ (Ultrafree-MC microcentrifuge filters, M0536, Sigma-Aldrich, (USA) and 
centrifuged for $30 \mathrm{~min}$ at $3500 \mathrm{~g}$ and $4{ }^{\circ} \mathrm{C}$. The solution that passed through the filter and proteins below $30 \mathrm{kDa}$ was collected in the "flow-through". The acid and salts were removed using a microtip filled with the Porous 50 R2 resin (PerSeptive Biosystems, Framingham, MA, USA), eluted with $50 \%$ acetonitrile $/ 0.2 \%$ formic acid, and dried in a Speed Vac (AS 290, Savant, Rochester, NY, USA) for $30 \mathrm{~min}$. The samples were reduced/alkylated and diluted five times with $100 \mathrm{mM}$ ammonium bicarbonate. Next, $0.5 \mu \mathrm{g}$ of trypsin was added to the samples, which were left to stand for $22 \mathrm{~h}$ at $37^{\circ} \mathrm{C}$. Finally, $5 \mu \mathrm{L}$ of formic acid were added, to quench the reaction. Thereafter, the supernatants were desalted using a microtip filled with Porous 50 R2 resin and dried for 10 min under vacuum. The samples were re-dissolved in a $5 \mathrm{mg} \cdot \mathrm{mL}^{-1}$ alpha-cyano-4-hydroxycinnamic acid (CHCA; Sigma-Aldrich) matrix with 50\% acetonitrile/0.1\% trifluoroacetic acid (TFA), followed by crystallization in a matrix-assisted laser desorption/ionization (MALDI) target. Then, MS was accomplished using a MALDI time-of-flight/ time-of-flight (MALDI-TOF/TOF) mass spectrometer (Axima Performance; Kratos-Shimadzu Biotech, Manchester, UK). External calibration of the mass spectrometer was performed using synthetic peptides (ProteoMass Peptide and Protein $\dot{s}$ Maldi-MS Calibration Kit; Sigma-Aldrich). The mass accuracy was $<50 \mathrm{ppm}$. Peptides were analyzed for mass precursor and ion precursor selection by data-dependent acquisition following high-energy collision-induced dissociation (CID) to produce product ions of each precursor ion. These ions were then used to determine the amino acid sequences.

With the Launchpad 2.8 software, the CID-MS/MS spectra were submitted to a database search using MASCOT version 2.2.04. Product ion spectra of tryptic peptides were subjected to protein identification by searching the SwissProt database version 2012x.fasta selected for the taxonomy filter of Homo sapiens (total sequences of 534,695 and sequences for $\mathrm{H}$. sapiens containing 20,321 sequences) using in-house MASCOT version 2.2.04. The database search parameters were no enzyme and Carbamidomethyl (C) as fixed modification. Oxidation (M) was considered a variable modification. Average mass values were used for the database search, with mass tolerance of 1.2 and $0.8 \mathrm{Da}$ for precursor and product ions, respectively. The search was conducted for both sequences predicted by trypsin cleavage, without constraint. A MASCOT score above 30 was considered for protein identification.

\section{Results}

This study recorded the mass spectra of 12 of the 14 collected teeth. The signal-to-noise ratio was too low for two teeth. Figure 1 contains representative spectra. The employed conditions enabled identification of amelogenin peptides with protein scores ranging from 52 to 108 only. It was not possible to identify other peptides, because their protein scores lay below 30 , which would not afford reliable
A

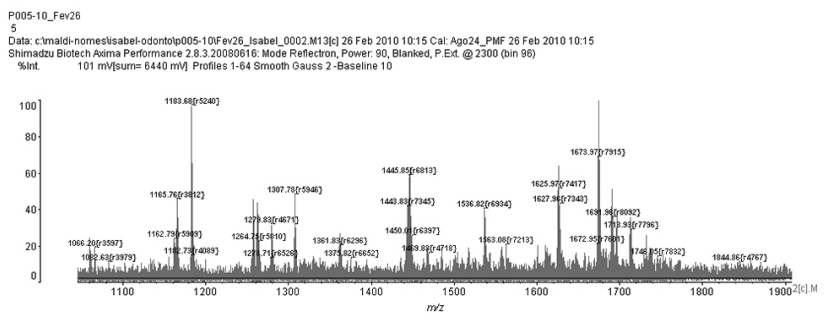

C

P005-10_Fer26

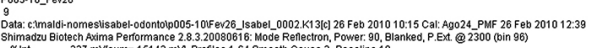
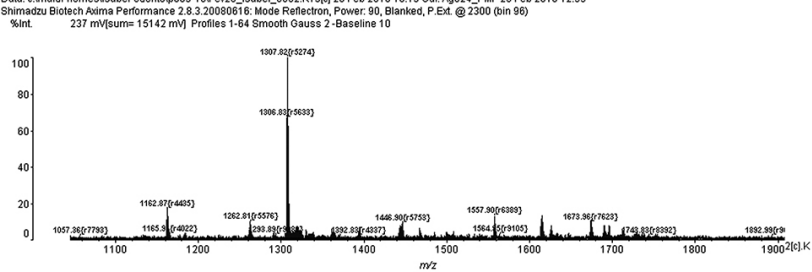

B
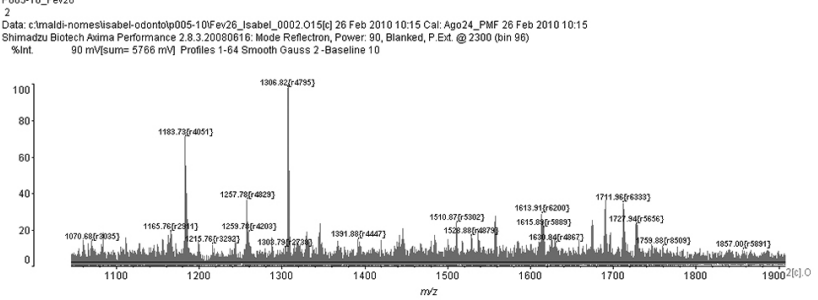

D

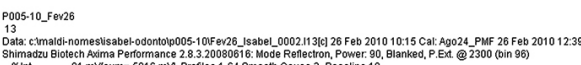

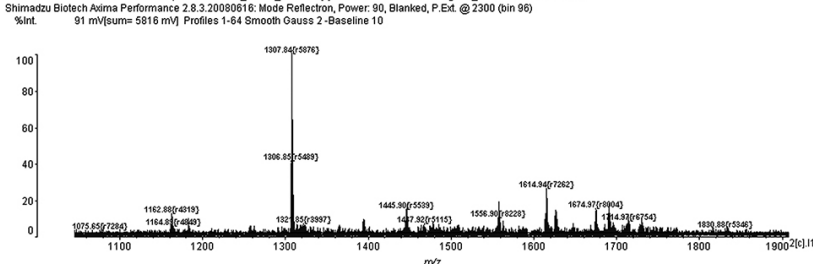

Figure 1. MS spectra of superficial enamel extracts of mature human teeth. A: Nonerupted fluorotic tooth. Two peptides of Amelogenin-X isoform have been identified (spectra of $\mathrm{m} / \mathrm{z} 1307.78$ and 1673.97, peptide sequences KWYQSIRPPYP and MPLPPHPGHPGYINF, respectively). B: Nonerupted control tooth. One peptide Amelogenin-X isoform was identified (spectrum of m/z 1306.82, peptide sequence WYQSIRPPYP).C: Erupted fluorotic tooth. One peptide Amelogenin-X isoform was identified (spectra of m/z 1307.82 and 1306.83, peptide sequence WYQSIRPPYP). d) Erupted control tooth. Three peptides of Amelogenin were identified (spectra of m/z 1306.80 and 1307.79, peptide sequences WYQSIRPPYP, and spectrum of m/z 1674.92, sequence MPLPPHPGHPGYINF). 
results. The data obtained here were in line with the previous results that our research group described when testing the use of a superficial etching technique to recover specific enamel peptides for the first time (18) and to recover contemporary and mummy teeth amelogenin sequences (19). The amelogenin peptides found here shared the same sequences as those already described in other studies. However, some contaminating proteins (contaminating in a sense that they were not enamel-specific) emerged in these other investigations, whereas the present work only detected amelogenin in amounts that rendered an adequate signal-to-noise ratio. In the present case, many steps involved in the procedure were accomplished inside the flow hood, and much more care was taken when manipulating the tubes and solutions. This probably resulted in lower amounts of contaminating proteins as compared with our previous reports. Careful analysis of the sequences did not identify other proteins in the mass spectra, which was an advantage of this methodology.

Figure 2 lists some of the sequences obtained from the enamel samples along with the peptide scores and the mass data. It was possible to identify only two amelogenin sequences in all the samples. The sequences spanned the major amelogenin-X sequence from amino acid 1 or 3-5 of the secreted protein (or 17 or 19-31, if one considers the signal peptide as the first amino acid) and 25-34, 2536 , and 25-37 when one starts with the first methionine

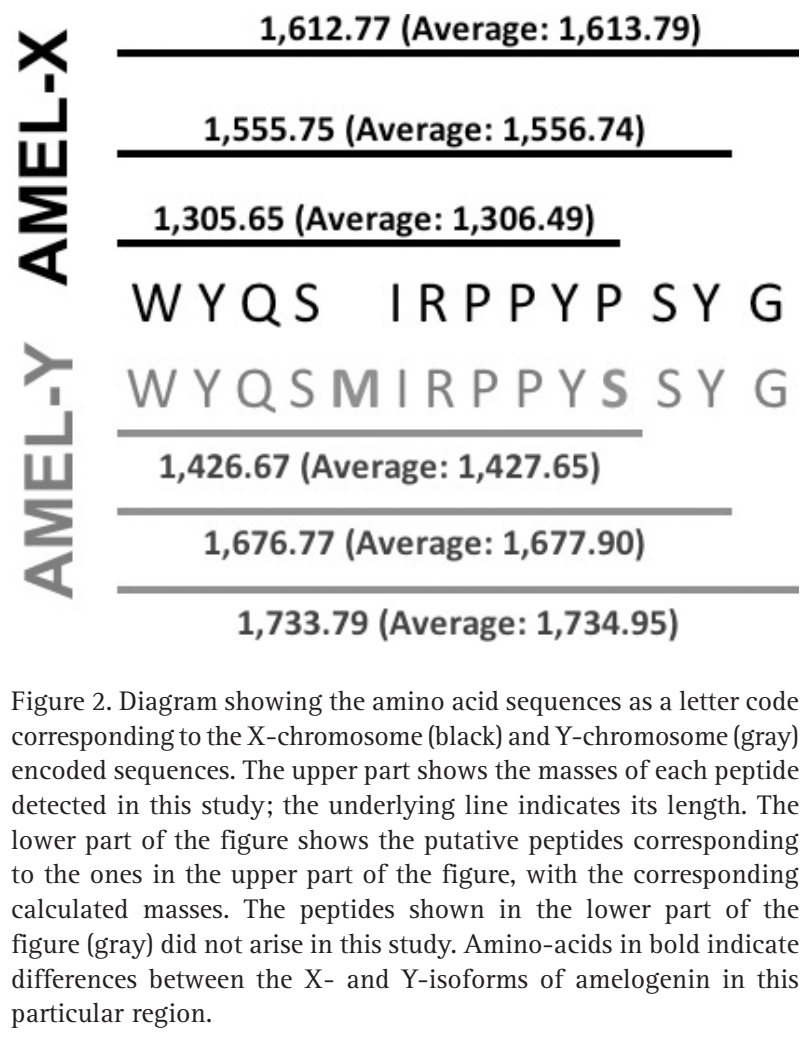

of the secreted protein (corresponding to 41-50, 41-52, and 41-53 when one considers the methionine from the signal peptide as the first amino acid). The first sequence resulted in signals with $\mathrm{m} / \mathrm{z}$ of 1690,1675 and 1445 . The second sequence appeared as peptides 1306, 1557 and 1613. The three peptides encoding this second sequence contained a tryptophan (W) on their $\mathrm{N}$-terminus, and this tryptophan came after a lysine (K). This lysine characterizes a trypsin cleavage site. On the C-terminus, the second sequence (WYOSIRPPYP) of peptides varied by two to three aminoacids in length. The $\mathrm{N}$-terminal amelogenin peptide was also variable: it sometimes started with methionine 1 and sometimes with leucine 3 . Overall, the groups did not differ in terms of the peptide length.

\section{Discussion}

Both sequences present in the enamel of the teeth analyzed in this study belong to the $\mathrm{N}$-terminus of amelogenin, confirming the long-held model that amelogenin hydrolysis proceeds from the C-terminus toward the N-terminus.

According to Wiedemann-Bidlack et al. (2011) "there are three discernable domains in the amelogenin molecule: a tyrosine-rich $\mathrm{N}$-terminal domain of 45 amino acids, a large hydrophobic central region comprised primarily of $X-Y-P$ repeat motives ( $P$, proline; $X$ and $Y$ are mostly glutamine), and a hydrophilic $\mathrm{C}$-terminus of 11 amino acids" (25). In the present study, the fact that the peptide recovered from the mature enamel originates from the $\mathrm{N}$-terminal region suggests that, during mineralization of dental enamel, this peptide remains inside the enamel to some extent, for some unknown reason.

This is the first study that has compared the amino acid sequences found in mature (or nearly mature) enamel of control and fluorotic teeth. The present work has not verified any differences between the teeth, which suggests that enamel proteinolysis proceeds and enamel peptides do leave the enamel even under exposure to high concentrations of fluoride during enamel development.

The results are also interesting because they confirm that Kalikrein-4 (KLK-4) is most likely the enamel proteinase that exhibits wide-range proteolytic ability and probably accounts for the observed cleavages. Nagano et al. (23) have shown that KLK-4 generates a sequence from pig TRAP (tyrosine-rich-amelogenin polypeptide) and LRAP (leucine-rich amelogenin polypeptide) that is exactly the one found in the present study (MPLPPHPGHPGYINF). The other peptide sequence, WYOSIRPPYP, corresponds to the other sequence (WYONMIR) characterized by Nagano et al. (23) in pig enamel peptides, which also originated from hydrolysis of TRAP and LRAP by KLK-4. Because the protein content in mature enamel is low, the two sequences 
observed here are probably the most abundant in mature enamel of both control and fluorotic teeth.

A very interesting finding of this study is that one of the detected sequences constitutes a dimorphic sequence - it holds two amino acid differences in the copies encoded in the $\mathrm{Y}$ and $\mathrm{X}$ chromosomes of humans. This study has only spotted the X-chromosome encoded sequence, but this peptide is potentially applicable in forensic and anthropological evaluations, since it is found in mature enamel. Figure 2 depicts the amino acid sequences predicted from the cDNA obtained from the $\mathrm{X}$ - and $\mathrm{Y}$-chromosome copies. This figure also shows the predicted differences in molecular masses, indicating that the masses obtained in this study are really incompatible with the Y-chromosome encoded amelogenin peptides.

The study of mature enamel peptides, and in the future the whole range of enamel peptides found in the different stages (and depths) of enamel will certainly help to elucidate the mechanism of dental fluorosis and other enamel defects. It is interesting that not all conditions where proteinolysis changes happen result in changes in the enamel: enamel defects. While fluoride has not been shown by all authors to inhibit enamel proteinases, other known inhibitors of proteinases (like lead and cadmium) have not been shown to alter dental enamel formation in the way fluoride does. The hardness of enamel generated under conditions of lead exposure, for instance, has already evidenced this-enamel in the early stage of maturation contains a larger amount of proteins, whereas more mature enamel does not display any defects or altered hardness (26). However, under lead-exposure conditions, enamel of continuously growing rat incisors takes longer to reach the oral cavity (27), suggesting that the longer eruption time promotes a compensatory mechanism. Such a mechanism may ensure that enamel achieves its high crystallinity, large mineral content and low amount of protein. It is important to discuss these protein/mineral aspects in continuously growing incisors of rats- to remember that the increased amount of protein described for enamel of fluorotic incisors in the early stage of maturation might not bear a causal relationship with the observed enamel defects. Indeed, it may be a consequence of the difficulties that peptides face when leaving the enamel, as already discussed by Aoba and Fejerskov (3). Human fluorotic lesions might pose a barrier of well-mineralized outer enamel along with underlying hypomineralized enamel (1). The presence of high fluoride concentrations probably induces the deposition of such barrier, because there are high amounts of fluoride in the outer enamel of human teeth (28). This most likely accounts for both organic matrix entrapment and the more porous/less mineralized sub-surface enamel that characterizes fluorotic enamel defects. Moreover, a barrier would impose difficulties to further gain of mineral that is essential for proper enamel mineralization. According to this reasoning, it is very important to know whether proteolysis follows the expected sequence in fluorotic enamel as compared with control enamel, or at least whether in the end the same proteolytic products are found. Recently, some light has been shed on the molecular mechanisms that are altered in fluorosis, particularly the importance of apoptosis that follows endoplasmatic reticulum stress (29), the inhibition of KLK4 via the TGF-beta1 pathway (30), and the discussion on the importance of barrier formation for the development of fluorotic enamel (31). Nonetheless, the precise characterization of the peptides in fluorotic enamel has not yet been made and this study contributed towards improving knowledge on this.

In conclusion, this study has shown that it is feasible to recover two $\mathrm{N}$-terminal sequences of amelogenin from mature and nearly mature enamel, and one of these sequences is specific for the X-chromosome. Fluorotic and control teeth are not different, which suggests that exposure to high concentrations of fluoride does not restrain the final degradation of polypeptides in dental enamel. Further studies on the peptides present in mature enamel will help elucidating many disturbances related to enamel formation.

\section{Resumo}

Exposição a altos niveis de flúor durante a amelogênese causa fluorose no esmalte. Este estudo tem como objetivo determinar e comparar as sequências de aminoácidos presentes no esmalte de dentes controles e fluoróticos. A investigação incluiu amostras de esmalte obtidas de terceiros molares erupcionados e não erupcionados, ambas ou com grau de fluorose TF 4-6 ( $n=7$ ) ou sem sinais de fluorose (controles, $n=7$ ), congelados a -20 $\mathrm{oC}$ até a extração das proteinas. As amostras sofreram ataque ácido e foram processadas utilizando um coquetel de inibidores de proteinases, sendo imediatamente analisadas. MALDI-TOF/TOF seguido pela pesquisa com MASCOT foram utilizados para a análise dos peptídeos. Os peptídeos mais abundantes foram das amelogeninas com sequências $\mathrm{N}$-terminal WYOSIRPPYP (que é codificada especificamente pela amelogenina X) e MPLPPHPGHPGYINF (que não apresenta dimorfismo sexual algum), não havendo diferenças entre dentes fluoróticos e controles. Nenhuma alteração na proteólise ocorreu nas amostras fluoróticas, o que sugere que 0 aumento na quantidade de proteinas existentes nas amostras fluoróticas não está correlacionada a habilidade das proteinases em clivar as proteínas em humanos. Este estudo mostrou como extrair com sucesso peptídeos do esmalte superficial. Um número relativamente baixo de dentes foram suficientes para se obter ótimos dados a respeito de peptídeos encontrados no esmalte maduro.

\section{Acknowledgements}

We gratefully acknowledge the support of the São Paulo State Research Foundation (FAPESP) and the Brazilian National Council for Scientific and Technological Development (CNPq).

\section{References}

1. Yanagisawa T, Takuma S, Fejerskov 0. Ultrastructure and composition 
of enamel in human dental fluorosis. Adv Dent Res 1989;3:203-210.

2. Saiani RA, Porto IM, Marcantonio Junior $E$, Cury JA, de Sousa $F B$, Gerlach RF. Morphological characterization of rat incisor fluorotic lesions. Arch Oral Biol 2009:54:1008-1015.

3. Aoba T, Fejerskov 0. Dental fluorosis: chemistry and biology. Crit Rev Oral Biol Med 2002;13:155-170.

4. Patterson CM, Kruger BJ. An autoradiographic study of the effect of a range of fluoride doses on the utilization of $(3-\mathrm{H})$-orotate by ameloblasts in the rat. Arch Oral Biol 1975;20:149-151.

5. Patterson $\mathrm{CM}$, Basford $\mathrm{KE}$, Kruger BJ. The effect of fluoride on the immature enamel matrix protein of the rat. Arch Oral Biol 1976;21:131-132.

6. Patterson CM, Kruger BJ, Daley TJ. Lipid and protein histochemistry of enamel effects of fluoride. Calcif Tissue Res 1977;24:119-123.

7. Smid JR, Kruger BJ. A microspectrophotometric analysis of the effect of fluoride on immature enamel matrix protein of rat molar teeth. Calcif Tissue Int 1980;30:57-66.

8. Smid JR, deJersey J, Kruger BJ. Effect of long-term administration of fluoride on the levels of EDTA-soluble protein and gammacarboxyglutamic acid in rat incisor teeth. J Dent Res 1984;63:10611063.

9. Den Besten PK. Effects of fluoride on protein secretion and removal during enamel development in the rat. J Dent Res 1986;65:1272-1277.

10. Den Besten PK, Heffernan LM. Enamel proteases in secretory and maturation enamel of rats ingesting 0 and 100 ppm fluoride in drinking water. Adv Dent Res 1989;3:199-202.

11. Gerlach RF, de Souza AP, Cury JA, Line SR. Fluoride effect on the activity of enamel matrix proteinases in vitro. Eur J Oral Sci 2000a;108:48-53.

12. Porto IM, Saiani RA, Andrew Chan KL, Kazarian SG, Gerlach RF, Bachmann L. Organic and inorganic content of fluorotic rat incisors measured by FTIR spectroscopy. Spectrochim Acta A: Mol Biomol Spectrosc 2010;77:59-63.

13. Porto IM, Merzel J, de Sousa FB, Bachmann L, Cury JA, Line SR, et al.. Enamel mineralization in the absence of maturation stage ameloblasts. Arch Oral Biol 2000;54:313-321.

14. Mangum JE, Crombie FA, Kilpatrick N, Manton DJ, Hubbard MJ. Surface integrity governs the proteome of hypomineralized enamel. J Dent Res 2010b;89:1160-1165.

15. Eastoe JE, Fejerskov 0. Composition of enamel proteins from fluorosed teeth. In: Tooth Enamel IV. Fearnhead RW, Suga S (Editors). Amsterdam: Elsevier Science Publishers; 1984. p.326-330.

16. Wright JT, Chen SC, Hall KI, Yamauchi M, Bawden JW. Protein characterization of fluorosed human enamel. J Dent Res 1996;75:19361941.

17. Porto IM, Line SR, Laure HJ, Gerlach RF. Comparison of three methods for enamel protein extraction in different developmental phases of rat lower incisors. Eur J Oral Sci 2006:114(Suppl 1):272-275.

18. Porto IM, Laure EJ, Sousa FB, Rosa JC, Gerlach RF. New techniques for the recovery of small amounts of mature enamel proteins. J Archaeol Sci 2011;38:3596-3604.

19. Porto IM, Laure EJ, Tykot RH, de Sousa FB, Rosa JC, Gerlach RF. Recovery and identification of mature enamel proteins in ancient teeth. Eur $J$ Oral Sci 2011b;119(Suppl 1):83-87.

20. Fukae M, Tanabe $T$, Uchida $T$, Lee $\mathrm{SK}_{1}$ Ryu $\mathbf{O H}$, Murakami $\mathrm{C}_{\text {, et al.. }}$ Characterization of recombinant pig enamelysin activity and cleavage of recombinant pig and mouse amelogenins. J Dent Res 1999;78:743750.

21. Chen WY, Bell AW, Simmer JP, Smith CE. Mass spectrometry of native rat amelogenins: primary transcripts, secretory isoforms, and C-terminal degradation. J Dent Res 2000;79:840-849.

22. Mangum JE, Kon JC, Hubbard MJ. Proteomic analysis of dental tissue microsamples. Methods Mol Biol 2010a;666:309-325.

23. Nagano T, Kakegawa A, Yamakoshi Y, Tsuchiya S, Hu JCC, Gomi K, et al.. MMP-20 and KIk4 cleavage site preferences for amelogenin sequences. J Dent Res 2009;88:823-828.

24. Marimon MP, Knoller K, Roisenberg A. Anomalous fluoride concentration in groundwater - is it natural or pollution? A stable isotope approach. Isotopes Environ Health Stud 2007;43:165-175.

25. Wiedemann-Bidlack FB, Kwak S-Y, Beniash E, Yamakoshi $Y$, Simmer $J P$, Margolis HC. Effects of phosphorylation on the self-assembly of native full-length porcine amelogenin and its regulation of calcium phosphate formation in vitro. J Struct Biol 2011;173:250-260.

26. Gerlach RF, Cury JA, Krug FJ, Line SR. Effect of lead on dental enamel formation. Toxicology 2002;175:27-34.

27. Gerlach RF, Toledo DB, Novaes PD, Merzel J, Line SR. The effect of lead on the eruption rates of incisor teeth in rats. Arch Oral Biol 2000;45:951-955.

28. Richards A, Likimani S, Baelum V, Fejerskov 0. Fluoride concentrations in unerupted fluorotic human enamel. Caries Res 1992;26:328-332.

29. Liu L, Zhang Y, Gu H, Zhang K, Ma L. Fluorosis induces endoplasmatic reticulum stress and apoptosis in osteoblasts in vivo. Biol Trace Elem Res 2015;164:64-71.

30. Suzuki $M$, Shin $M$, Simmer JP, Bartlett JD. Fluoride affects enamel protein content via TGF- $\beta 1$-mediated KLK4 inhibition. J Dent Res 2014;93:1022-1027.

31. Lyaruu DM, Medina JF, Sarvide S, Bervoets TJ, Everts V, Denbesten P, et al.. Barrier formation: potential molecular mechanism of enamel fluorosis. J Dent Res 2014;93:96-102. 